\title{
THE "CONSPIRACY THEORY" OF THE FOURTEENTH AMENDMENT
}

\author{
By HOWARD JAY GRAHAM $\dagger$
}

"No state shall . . . deprive any person of life, liberty, or property without due process of law, nor deny to any person. . . the equal protection of the law's."

\section{Section 1, Fourteenth Aarendarent}

IN AN argument before the Supreme Court of the United States in $1882^{1}$ Roscoe Conkling, a former member of the Joint Congressional Committee which in 1866 drafted the Fourteenth Amendment, produced for the first time the manuscript journal of the Committee, and by means of extensive quotations and pointed comment conveyed the impression that he and his colleagues in drafting the due process and equal protection clauses intentionally used the word "person" in order to include corporations. "At the time the Fourteenth Amendment was ratified," he declared, "individuals and joint stock companies were appealing for congressional and administrative protection against invidious and discriminating State and local taxes. One instance was that of an express company, whose stock was owned largely by citizens of the State of New York . . ." The unmistakable inference was that the Joint Committee had taken cognizance of these appeals and had drafted its text with particular regard for corporations.

Coming from a man who had twice declined a seat on the Supreme Bench, ${ }^{2}$ who spoke from first hand knowledge, and who submitted a manuscript record in support of his stand, so dramatic an argument could not fail to make a profound impression. Within the next few years the Supreme Court began broadening its interpretation of the Fourteenth Amendment, and early in 1886 it unanimously affirmed Conkling's proposition, namely that corporations were "persons" within the meaning of the equal protection clause. ${ }^{3}$ It is literally true therefore

$\dagger$ Research Fellow in Political Science, University of California.

1. See San Mateo County v. Southern Pacific R.R., 116 U. S. 138. A printed copy of the Oral Argument of Roscoe Conkling is preserved in a volume entitled Sax: Mateo Case, Argunrents and Decisions, in the Hopkins Railroad Collection of the Library of Stanford University. It is this copy which the author has used, and which he cites hereafter as ConkLing's Argument.

2. Once as Chief Justice, vice Chase, in 1873; again as Associate Justice, vice Hunt, in 1882. Chief Justice Waite and Justice Blatchford thus both occupied seats which had been declined by Conkling.

3. See Waite, J., in Santa Clara County v. Southern Pacific R.R, 118 U. S. 394, 396 (1886). This case involved the same questions as the Sor Mafeo case argued three years before. 
that Roscoe Conkling's argument sounded the death knell of the narrow "Negro-race theory" of the Fourteenth Amendment expounded by Justice Miller in the Slaughter House cases. By doing this it cleared the way for the modern development of due process of law and the corresponding expansion of the Court's discretionary powers over social and economic legislation. Viewed in perspective, the argument is one of the landmarks in American constitutional history, an important turning point in our social and economic development.

Conkling's argument has figured prominently in historical writing since 1914 when B. B. Kendrick unearthed and edited the manuscript copy of the Journal which Conkling used in court. ${ }^{4}$ Checking the record in the light of his major propositions, historians became convinced of the fundamental truth of Conkling's story. Repeatedly, it appeared from the Journal, the Joint Committee had distinguished in its drafts in the use of the words "person" and "citizen." Under no circumstances could the terms have been confused. Moreover, as the Committee had persistently used the term "person" in those clauses which applied to property rights and the term "citizen" in those clauses which applied to political rights, the force of this distinction seemed plain : corporations as artificial persons, had indeed been among the intended beneficiaries of the Fourteenth Amendment. Convinced on this point, historians developed an interesting theory: the drafting of the Fourteenth Amendment had assumed something of the character of a conspiracy, with the due process and equal protection clauses inserted as double entendres. Laboring ostensibly in the interests of the freedmen and of the "loyal white citizens of the South," the astute Republican lawyers who made up the majority of the Committee had intentionally used language which gave corporations and business interests generally increased judicial protection as against State legislatures.

4. The Journal of the Joint Comaittee of Fifteen on Reconstruction (1914). The Journal itself is printed in Part I, pp. 37-129. The "Introduction," pp. 17-36, gives an interesting account of its history and the circumstances of discovery. It is revealed that 6,000 copies of the Journal were printed by the order of the Senate in February, 1884 (while the San Mateo case was still before the Supreme Court). For some unexplained reason these copies never circulated, a single printed copy of the edition being preserved in the Government Printing Office. This copy was used by Horace E. Flack in the preparation of his monograph, THE AnOption of THE FounTEENTH AMENDMENT (1908). But it was not until 1911 and the publication of Hannis Taylor's The Origin and Growth of the American Constitution (1911), whercin attention was directed to Conkling's argument, that the full historical importance of the manuscript was noted. It should be added that Professor Kendrick was concerned with the bearing of the Journal on matters pertaining to Reconstruction, and referred only incidentally to the later use made by Conkling. This fact explains the failure to note the discrepancies in Conkling's quotations from the Journal.

5. KENDRICK, op. cit. supra note 4 , at $50-51,56,60-61$ for striking examples. 
What appeared to be corroboration for this viewpoint was presently found in the speeches ${ }^{6}$ of Representative John A. Bingham, the Ohio Congressman and railroad lawyer who almost alone of the members of the Joint Committee had been responsible for the phraseology of Section One. Bingham, it appeared both from the Journal and the debates on the floor of the House, had at all times shown a zealous determination to secure to "all persons" everywhere "equal protection in the rights of property." 7 Moreover, he had evinced an extraordinary preference for the due process clause and had developed and defended its phraseology in most vigorous fashion. As no other member of the Joint Committee, or of Congress, gave evidence of a similar desire to protect property rights, and none manifested his partiality for the due process clause, it seemed logical to conclude that Bingham's purposes had in fact been far more subtle and comprehensive than was ever appreciated at the time. Bingham had been the master-mind who "put over" this draft upon an unsuspecting country. The fact that he had tried and failed to secure the inclusion of a "just compensation" clause in Section One as still another restraint upon the States' powers over property, ${ }^{8}$ and the fact that in $1871,{ }^{9}$ five years after the event, he declared he had framed the section "letter for letter and syllable for syllable" merely served to strengthen these suspicions.

Impressed by this cumulative evidence, and alive to its historical implications, Charles A. and Mary R. Beard, in 1927, developed in their Rise of American Civilization what is still, a decade later, the most precise statement of the conspiracy theory. Undocumented, and with conclusions implicit rather than explicit, the Beards' thesis was this: Bingham, "a shrewd . . . and successful railroad lawyer, . . . familiar with the possibilities of jurisprudence," had had much broader purposes than his colleagues. Whereas they were "bent on establishing the rights of Negroes," he was "determined to take in the whole range of national

6. Cong. GLobe, 39th Cong., 1st Sess. (1866) 429, 1034, 1064-1065, 1059-1095, 1292 .

7. Originally Bingham's draft was phrased in the positive form: "Congress sholl have power to make all laws necessary and proper to secure to all persons in every State within this Union equal protection in their rights of life, liberty and proparty:" Later, a clause was added giving Congress power to "secure to all cilizens the same immunities and also equal political rights and privileges." These clauses vere the embryonic forms out of which the later phraseology developed. Early drafts made no mention of "due process of law." Not until the House had virtually rejected the Amendment on the grounds that it gave Congress too sweeping powers-thus compelling a change from the early positive to the present negative form ("no State shall ...") - was the due process phraseology inserted. Bingham's carly speeches reveal, however, that he had had due process of law in mind from the very beginning.

8. KENDRICK, op. cit. supra note 4, at 85 . Bingham made this attempt at the meeting of the Committee on April 21, 1866. The adverse vote was 7 to 5, with three members absent.

9. Cong. Record, 42nd Cong., 1st Sess. (1871) Appendix, at 83-85. 
economy." Toward this end he had drafted the due process and equal protection clauses and forced them upon the Committee by persistent efforts. Quoting Bingham's speeches and Conkling's argument in support of the view that corporations had been among the intended beneficiaries of the draft, the authors concluded : ${ }^{10}$

"In this spirit, Republican lawmakers restored to the Constitution the protection for property which Jacksonian judges had whittled away and made it more sweeping in its scope by forbidding states, in blanket terms, to deprive any person of life, liberty, or property without due process of law. By a few words skillfully chosen every act of every state and local government which touched adversely the rights of persons and property was made subject to review and liable to annulment by the Supreme Court at Washington."

Thus, while the Beards nowhere expressly state that Bingham was guilty of a form of conspiracy, this is none the less a fair inference from their account, and it is one which has repeatedly been drawn. Numerous writers, ${ }^{11}$ accepting the Beards' account and popularizing it, have supplied more explicit interpretations. Thus, E. S. Bates, in his Story of Congress, declares that Bingham and Conkling in inserting the due process phraseology, "smuggled" into the Fourteenth Amendment "a capitalist joker."12

Despite widespread acceptance and a prestige which derives from the Beards' sponsorship, the conspiracy theory has not gone unchallenged. Numerous writers have expressed varying degrees of disapproval and skepticism. ${ }^{13}$ Constitutional historians in particular appear reluctant to accept its implications, although they, no more than the sponsoring school of social historians, have as yet presented thẹir case in documented detail. One thus observes the curious paradox of a theory which cuts across the whole realm of American constitutional and economic history and which

10. Vol. II, p. 111-113 (italics added).

11. See, e.g., Lerner, The Supreme Court and American Capitalism. (1933) 42 Yale L. J. 668, 691; DaggetT, Principles of Inland Transportation (1934) 436437; Josephson, The Robber Barons (1934) 52.

12. At 233-234.

13. Louis Boudin has referred with obvious irritation to the "legendary history of the Fourteenth Amendment" and has threatened a monograph in disproof of "pseudo history" sponsored by certain "eminent historians." 2 GoverNMENT BY JUDICLARY (1932) 404. More precise and dispassionate, Walton H. Hamilton has objected that the theory "endows the captains of a rising industry with a capacity for forward plan and deep plot which they are not usually understood to possess." Property-According to Locke (1932) 41 Yale L. J. 864, 875. Finally, E. R. Lewis, the most recent writer to examine the matter in the light of both the published Journal and the Congressional debates, has emerged frankly skeptical of Conkling's whole story and inclined to demand morc convincing evidence. A History of American Political Thougrt from the Civir WAR TO THE WORLD WAR (1937) $28 \mathrm{ff}$. 
is itself a subject for increasing speculation and controversy, yet which has developed piecemeal, without systematic formulation or criticism.

How extraordinary certain aspects of this situation are may be judged from the fact that one is now left wholly in the dark as to the nature and degree of conspiratorial intent imputed to Bingham and his colleagues. Is one to believe, for example, that these men determined from the first to devise phraseology which included corporations? Or simply that they later perceived it possible, or advantageous, to do so? Again, what type of protection did the framers contemplate within the meanings of the due process phrase? Protection in the modern substantive sense? Or simply protection against arbitrary procedure? If simply the latter was intended, the "conspiracy" was scarcely worthy of the name, for to have used "person" and "due process" in this manner would have been natural for any" well. informed lawyer of 1866, whatever may be said of the understanding of the layman. On the other hand, to have applied due process substantively with regard to corporations in 1866 would have been a thoroughly revolutionary step, even for a lawyer. For this reason it is a substantive usage that is most consistent with the theory. In both of these issues the implied difference in motive is great; and likewise the implied ambiguity in the theory. The matter of motive and intent would seem to be too fundamental an element of conspiracy to leave in so unsatisfactory a state.

It is the purpose of this article to re-examine the conspiracy theory and to determine, insofar as possible, the extent to which it meets certain essential conditions.

\section{Conkling's Argument Re-examined}

$A$ priori, there are two major reasons for being skeptical of a declaration that the framers of the Fourteenth Amendment aimed to aid business interests when they devised the due process and equal protection clauses. First, as we have just seen, such a declaration virtually demands as its major condition that John A. Bingham and the other members of the Joint Committee regarded due process of law as a restraint upon the substance of legislation at the early date of 1866 , whereas due process was at this time, with a few striking exceptions, ${ }^{14}$ merely a limitation upon procedure. The theory thus presupposes that the drafters assumed what was really an extraordinary viewpoint: it endows them with re-

14. The two most conspicuous were Chief Justice Taney's dictum in the Dred Scott case [19 Howard 393 (U. S., 1856)] and the various dicta in the New Yorls liquor case of Wynehanier v. People [13 N. Y. 378 (1856)]. For the development of due process of law before the Civil War, see Howe, The Mleaning of Dse Process Prior to the Adoption of the r4th Amendment (1930) 18 CALrr. I. REv. 583; Corwin, The Doctrine of Due Process of Law Before the Civil War (1911) 24 Hanv. L. REv. $366,460$. 
markable insight and perspicacity. The second objection is that, as an apparent explanation of the Committee's choice of the word "person" in preference to "citizen," the theory ignores the fact that "person" was really the term employed in the Fifth Amendment, the phraseology of which Bingham simply copied. Further, in line with this last point is the fact that "persons," as a generic term and as a device employed in the original Constitution to refer to Negro slaves, ${ }^{16}$ clearly included "persons" of the Negro race and may logically have been preferred for this reason, since grave doubt existed as to whether Negroes were "citizens," and troublesome problems of definition arose if one tried to speak of them in still more precise terms.

The obstacles which these facts throw in the way of the conspiracy theory are at once apparent. Granted that Bingham's speeches reveal a solicitude for property rights not found in the speeches of his colleagues, granted that his drafts of the Amendment were couched in much broader language than those of his associates - in language which today "takes in the whole range of national economy" - still, it hardly follows that Bingham in 1866 was thinking of corporations as the beneficiaries of his drafts, nor that he regarded due process in the modern substantive sense. He may, conceivably, have used the words "any person" merely as a sure means of including Negroes as well as whites; he may also have used "due process of law" as a sure means of guaranteeing fair trial and fair procedure to all natural persons. In fact, so long as these were the prevailing usages down to 1866 one is hardly warranted in attributing a more subtle or comprehensive purpose to Bingham without definite, positive evidence. To do otherwise is to risk interpreting Bingham's purposes in the light of subsequent events.

So long as these fundamental objections place serious obstacles in the path of the theory, the question at once arises whether the direct statements made by Conkling in 1882 are alone sufficient to sustain it. If they are not, search must be made for new evidence, and the whole problem of the circumstantial materials in Bingham's speeches must be thoroughly canvassed.

An examination of Conkling's argument properly becomes the starting point of our inquiry. To facilitate later discussion, an analytical abstract of his argument will be presented:

1. Conkling's basic proposition, inferred at the outset, was that the Committee had had two distinct and clearly defined purposes. The first of these "related chiefly to the freedmen of the South" and dealt with the "subject of suffrage, the ballot, and representation in Congress." The second was broader and far more important, namely, to frame an

15. Art. I, §2, par. 3 ; Art. IV, §2, par. 3. 
amendment which would secure universal protection in the rights of life, liberty, and property. ${ }^{16}$

2. Having drawn this division in the agenda, he now declared, and offered extensive quotations from the Journal designed to show, that before the Committee undertook the second of these tasks - i.e., the task of framing what later became the due process and equal protection clauses - it had in fact "completely disposed of" and "lost all jurisdiction and power over" the first, i.e., "the portion which did in truth chiefly relate to the freedmen of the South."

3. His quotations from the Journal were also designed to show that the Committee had throughout its deliberations repeatedly distinguished between "citizens" and "persons," and that it had in general used "citizens" in the clauses designed to secure political rights and privileges (i.e., in what later became the privileges and immunities clause) and had used "persons" in the clause designed to secure "equal protection in the rights of life, liberty, and property." 18

4. He even quoted from the minutes to show that on one occasion he himself had moved to strike out of a draft "citizens" and substitute "persons." 19

5. Most important of all, he gave his listeners to understand - even emphasized the fact - that the draft of the equal protection clause as originally reported by a sub-committee had itself specified "citizens," and it is questionable, from a close reading of the argument, whether his listeners may not have gained the impression that it was he, Conkling, who had been responsible (by the previously mentioned motion) for the substitution of "persons" for "citizens" in this clause."

6. Without laboring his point, and relying on his listeners to recall that in the final draft of the Amendment the privileges and immunities clause applied to "citizens," and the due process and equal protection clauses to "persons," Conkling asked in conclusion if this record did not show that "the Committee understood what was meant" when it used these different terms. ${ }^{21}$

7. Apparently to remove all doubt on this score, Conkling casually added, "At the time the Fourteenth Amendment was ratified . . . individuals and joint stock companies were appealing for congressional and administrative protection against invidious and discriminating State and

16. Conkrno's ARguarent, op. cit. supra note 1, at 13-15.

17. Id., at $15,19,20$. Note the inference of the modifier "which did in truth chiefly relate." Conkling's argument abounds with such subtle suggestions of a broader and undeclared purpose.

18. Id., at 17-19, 23, 24 .

19. Id., at $18,19$.

20. Id., at 17-19.

21. Id., at 24,25 . 
local taxes" - inferring that the Committee had taken cognizance of this situation and that a desire to protect corporations had been the real explanation for maintaining the distinction between "citizens" and "persons." 22

Two features of Conkling's argument, which in many respects is a masterpiece of inference and suggestion, are now to be stressed. First, nowhere does Conkling explicitly say that the Committee regarded corporations as "persons"; nowhere does he say that the members framed the due process and equal protection clauses with corporations definitely in mind. These are simply the casual yet unmistakable impressions gained from dozens of hints, intimations, and distinctions made throughout his argument. The second feature, somewhat surprising in the light of the first, is that in his conclusion Conkling not only failed to press his points but, on the contrary, now substantially waived them. "I have sought to convince your honors," he said, "that the men who framed . . . the Fourteenth Amendment must have known the meaning and force of the term 'persons'," and in the next sentence he spoke significantly of "this surmise." ${ }^{23}$ Later, in his peroration, he freely admitted the difficulties of the proposition he had maintained. "The statesman," he declared, "has no horoscope which maps the measureless spaces of a nation's life, and lays down in advance all the bearings of its career." Finally, he concluded in this vein, "Those who devised the Fourteenth Amendment may have builded better than they knew . . . To some of them, the sunset of life may have given mystical lore."24

These quotations reveal an equivocal and indecisive element in Conkling's argument, and they provoke various questions. Why, if he had definite knowledge that the Joint Committee really framed the Amendment to include corporations, did he adopt this peculiar, tenuous, and indirect means of saying so? Why, after laboring to give the impression of intent, did he himself at times seem to belie that impression by use of such indecisive language? Was this simply a lawyer's caution, a desire for understatement? Was it because he felt that suggestion might here prove a stronger weapon than detail? Was it because he feared too concrete an account of unwritten history might harm his cause? Or was it because of some inherent weakness - even absence - of fact in his argument? A critical reader must puzzle over these questions and a cautious one will seek for tangible answers. In this connection several tests come to mind. Does Conkling's argument bear evidence of a scrupulous regard for facts, first in its major propositions, second in its essential details? Is it inherently consistent? Does it bear evidence of care and good faith in quotation from the Journal?

22. Id., at 25 .

23. Id., at 31 (italics added).

24. Id., at 33, 34 (italics added). 
Application of these tests to the more than twenty pages of Conkling's argument leads to some startling discoveries. Not only does it appear as a result of such an inquiry th.at Conkling suppressed pertinent facts and misrepresented others, but it is hard to avoid the conclusion that he deliberately misquoted the Journal and even so arranged his excerpts as to give listeners a false impression of the record and of his own relation thereto. In framing a bill of particulars, the following may be set down in refutation of his major points:

1. With regard to his fundamental proposition that the Joint Committee had been charged with two distinct, clearly defined purposes and that these two purposes had at all times been kept separate and distinct, it is sufficient to say that Conkling himself quoted ${ }^{20}$ a resolution in the Journal which effectively disposed of his point. This resolution, introduced in the Joint Committee by Senator Fessenden on January 12, 1866 , reads as follows: ${ }^{26}$

"Resolved that . . the insurgent States cannot . . be allowed
to participate in the Government until the basis of representation
shall have been modified, and the rights of all persons amply secured
..."

Obviously this resolution specified two tasks for the Joint Committee. But the important fact, not mentioned by Conkling and even disguised by him, was that it specified both tasks with regard to the "insurgent States." This being the case, it is hard to see how the two purposes could ever have been "separate and distinct" in the sense which Conkling contended, and harder still to believe that only those portions of the Fourteenth Amendment relating to "representation, the suffrage," etc, dealt exclusively with conditions in the South. The "insurgent States" reference practically destroys Conkling's case at the outset. His argument is rendered suspect by one of his own citations from the Journal. Only by laying emphasis upon Fessenden's use of the word "persons" in this resolution did Conkling steer listeners past this flaw in his case.

2. Auxiliary to his main proposition, Conkling was at great pains to show ${ }^{27}$ that the text of Bingham's Amendment, which originally read "Congress shall have power . . . to secure to all persons equal protection in the enjoyment of life, liberty and property," had been dealt with by the Committee as if members had at all times regarded it as distinct in both subject matter and purpose from the other amendments dealing with suffrage and representation. His particular point in this connection was that on January 24, 1866 the Bingham Amendment had been referred

25. Id., at 16 .

26. Kendrick, op. cit. sipra note 4, at 42 (italics added). Cited hereafter as the Fessenden resolution.

27. See note 17 , supra. 
to a different sub-committee than the one that had considered the other drafts. What Conkling neglected to say was that when Bingham originally introduced this draft on January 12,1866 , it had been referred, at Bingham's own motion, to "the sub-committee on the basis of representation" - the same sub-committee, in short, which received the other drafts. ${ }^{28}$ This appears to be a damaging omission, for it suggests that Bingham himself may have regarded his draft merely as one which, applying to "the insurgent States," "amply secured the rights of all persons," thus, perhaps, effectuating the second purpose outlined in the Fessenden resolution.

Whether this last interpretation is warranted or not, failure to mention the fact that Bingham's draft had originally been referred to the "stibcommittee on the basis of representation" led Conkling into embarrassing difficulties - difficulties from which he extricated himself only by strategem. We need here say no more than that at one point in his argument ${ }^{20}$ Conkling quoted this passage from the Journal :30 "The Committee proceeded to the consideration of the following [i.e., Bingham] amendment . . proposed by the sub-committee on the basis of representation." Obviously, to have read the text in this form would have been to risk wiping out the very impression which he was laboring to establish, namely that the Bingham Amendment was a thing apart, and one dealt with by a separate sub-committee - the "sub-committee on the powers of Congress." If we judge by his printed argument, Conkling extricated himself from this hole by pausing after the word "sub-committee" - i.e., by inserting a comma in the written text - so that the reported passage reads as follows: $:^{31}$

"The Committee proceeded to the consideration of the following amendment . . . proposed by the sub-committee, on the basis of representation: 'Congress shall have power to make all laws necessary and proper to secure to all citizens of the United States in each State the same political rights and privileges, and to all persons in every State equal protection in the enjoyment of life, liberty, and property.".

By thus splitting off the final phrase, and relating it not to its proper antecedent "sub-committee" but to the text of the Amendment which followed, Conkling salvaged his case. The fact that intrinsically the Bingham Amendment had nothing whatever to do with "the basis of representation," that it thus belied Conkling's motivating phrase, was probably not perceived by his listeners for the reason that this point

28. KendRICK, op. cit. supra note 4 , at 46 .

29. ConkLing's ARgument, op. cit. supra note 1, at 20.

30. KENDRICK, op. cit. supra note 4 , at 54 (italics added).

31. See note 29 , supra (italics in original). 
was inconsequential to his main argument, and that in the reading of the text he laid great stress on Bingham's use of the word "persons," thus directing thought in other channels.

3. Turning now to Conkling's second proposition, one finds the evidence almost as damaging. Again and again Conkling intimated that the real reason Bingham and the Joint Committee used the term "persons" instead of "citizens" had been to include corporations. Close examination not only fails to substantiate this statement but even provides an alternative explanation. One discovers the word "persons" used in numerous contexts which suggest that the real reason for preferring the term to "citizens" was that the freedmen, as natural beings and former slaves, were unquestionably to be regarded as "persons," whereas numerous complications arose whenever one attempted to speak of them, or even to define them, as "citizens." 32

Nowhere is this shown to better advantage than in a draft of an amendment which Conkling himself sponsored, ${ }^{33}$ and from which, with rare audacity, he quoted in argument. ${ }^{34}$ "Whenever in any State," he read, making clear that the text was his own, "civil or political rights or privileges shall be denied or abridged on account of race or color, all persons of such race or color shall be excluded from the basis of representation." One naturally wonders whether we do not have here a clue to the intended scope of the term "persons," and to the fundamental reason for choosing it. ${ }^{35}$ Surely the reference to "all persons of such race or color" suggests an explanation quite as plausible as Conkling's. It does not preclude the possibility of mixed or compound motives in determining the use of the term; it simply cautions against assuming

32. Passages in the Journal (Kendrick, op. cit. supra note 4, at 42-44, resolution of $\mathrm{Mr}$. Williams and Mr. Conkling; at 50-51, report of sub-committee) indicate that the Joint Committee, confronted early in its deliberations with the problem of how best to refer to the Negroes, divided into two groups. The first group, led by Conkling and Bingham, preferred to use the inclusive term "persons" throughout. The second group, led by Stevens, preferred the narrower term "citizens" with an added clause defining citizenship in such manner as to include Negroes. The dangers of ambiguity in definition apparently weighed heavily in the minds of all, for when the question finally came to a vote, the Bingham-Conkling form was adopted and Stcrens withdrew his motion. Id., at 52-53. It was not until much later, when the final draft of the amendment was before the Senate, that the first sentence of Section 1, which now defines citizenship, was added.

33. KENDRICK, op. cit. ripra note 4 , at 44.

34. Conkling's Argunent, op. cit. sipro note 1 , at 16.

35. This view is strengthened when one discovers that on April 21, 1866 the Joint Committee approved the following phraseology as a final draft of Section 1: "No discrimination shall be made by any state, nor by the United States, as to the civil rights of persons because of race, color, or previous condition of servitude." KEsinsuck, op. cit. supra note 4, at 83-85. Bingham's phraseology was finally substituted on April 28, 1866, after some surprising reversals in voting. Id., at 106. 
that a single explanation is necessarily adequate and that other possibilities may be ignored. ${ }^{36}$

4. Doubtless the most impressive point made by Conkling, so far as the Justices of the Supreme Court were concerned, was to the effect that Bingham's Amendment, as originally reported by the sub-committee, used the word "citizens" throughout; "persons," he emphasized by implication, appeared nowhere in the text. ${ }^{37}$ What gave real significance to this point was that Conkling had earlier emphasized that the text as originally introduced by Bingham, and ordered referred to the sub-committee, read, "Congress shall have power . . . to secure to all persons equal protection in the enjoyment of life, liberty and property." Recalling this emphasis, listeners could hardly have failed to have been impressed. For not only did it follow that the sub-committee had stricken out. "persons" and substituted "citizens" in this early draft of what eventually developed into the equal protection and due process clauses, but it followed further, since in the ultimate form both clauses applied to "persons," that at some stage or other - Conkling did not say when, or touch directly upon this point - the broader of the two terms had been reinstated. Obviously the mere fact of these successive deletions and insertions justified a view that the Committee had framed these clauses carefully, with utmost discrimination. And Conkling's statement regarding the joint stock companies provided a plausible reason.

To remove the underpinning from this part of the argument - and virtually from Conkling's entire case - one has to say merely that neither the sub-committee, nor anyone, at any time or under any circumstances, so far as the historical record indicates, ever used the word "citizen" in any draft of the equal protection or due process clauses. "Persons" was the term used by Bingham; 38 "persons" was the term reported by the sub-committee ;3 "persons" was the term discussed and approved by the Committee as a whole. ${ }^{40}$ Conkling misquoted the Journal in his argt1-

35. Further evidence which suggests that the word persons may not originally have been used with any subtle or devious intent is found in the text of the Fessenden resolution, supra note 26 . It will be recalled that this resolution specified that "the rights of all persons" must be "amply secured," but that it so specified only with regard to the "insurgent States." This being the case, and in view of the advantages of referring to Negroes as "persons," it seems gratuitous for Conkling to have asked with regard to this resolution, why, if Fessenden intended only to "bespeak protection for the black man of the South, he should choose these general, sweeping, if not inapt words." One can never know with certainty whether Fessenden regarded corporations as "persons" within the meaning of this resolution, but one rather marvels at Conkling's audacity in intimating that Fessenden did.

37. See supra, note 20.

38. KENDRICK, op. cit. supra note 4 , at 46 .

39. Id., at 51,56 .

40. Id., at 60-61, 82-107. 
ment, and it is almost impossible to believe that he did not do this intentionally. The reason is that he paused, repeated, and rhetorically underscored the misquoted word "citizen" so that the passage, as it appears in the printed argument, ${ }^{41}$ reads as follows:

"Now come the independent article:

'Article - Congress shall have power to make all laws necessary and proper to secure to all citizens of the United States, in every State, the same political rights and privileges; and to all citizens in every State'.

"I beg your Honors to remark that the term here employed was 'all citizens in every State' . . . 'cqual protection in the cnjoyment of life, liberty, and property'." 42

So long as the presumption must be strongly against a mere lapse on Conkling's part, the question necessarily arises what he could obtain by so bold a move. The reader must remember in this connection that Conkling predicated his entire case on the distinction between the meaning of the terms "citizen" and "person," and that the effect therefore was immeasurably to strengthen his hand. Another aspect of the matter is that it is questionable from a reading of the argument, particularly from the standpoint of one hearing it delivered orally for the first time, whether, in the passage immediately following, listeners may not have received the impression that Conkling himself was responsible for the substitution of the word "persons" for "citizens" in this embryo equal protection-due process clause. The reason for this belief is that Conkling went on to quote excerpts from the Journal which showed that he had himself moved to substitute "persons" for "citizens" in one draft,"3 and that he stated, but did not emphasize, that this motion to substitute was really with reference to one of the earlier quoted articles relating to representation and suffrage. ${ }^{44}$ The question, therefore, is whether his

41. P. 18.

42. It is sufficient to point out that the emphasis and underscoring eliminate the possibility of a mere verbal slip on Conkling's part in substituting "citizens" for "persons." And this appears to leave but one alternative, the possibility that Conlling really intended to emphasize the use of the word "citizens" in the first clause rather than in the second. Yet a rereading of his text with this object in mind reveals the unlikelihood of such an explanation-if for no other reason than that it requires his maling not one verbal slip, but two, and that together these would have so altered his meaning as to make their delivery and oversight appear improbable.

43. See supra note 19.

44. Article $B$ as reported in the Journal. Kendrick, op. cil. supra note 4, at 50-51. Conkling had quoted Article B, and its alternative form, Article A, on pages 17-18 of his argument, but immediately after doing this he had also quoted Bingham's "independent article." Confusion might very easily arise from failure to malse clear that his motion to substitute thus applied to Article B, particularly since its phraseology was of little apparent interest. 
listeners - who must have been highly impressed by his dramatic underscoring of the misquoted word "citizens," and who were probably still wondering when the word "persons" had eventually been reinstated did not jump to the conclusion, unwarranted by a close reading of the argument, that Conkling was himself the man responsible for this change. In view of these circumstances, it can be seen that Conkling undoubtedly gained a great deal from this part of his argument. Whether, and to what extent, his gains were the result of deliberate plan and artifice can never be known with certainty - and one must recognize some of the same pitfalls in imputing plot and design to Conkling as we have already mentioned in the case of Bingham ${ }^{45}$ — but the present writer is convinced that the foregoing evidence is most reasonably explained as a deliberate misuse of facts. To say this is not to say that the Joint Committee may not have regarded corporations as "persons;" that, indeed, is a question which depends upon many things. It is simply to say that Conkling could not prove his proposition from the Journal itself. In making the attempt, therefore, he resorted to misquotation and unfair arrangement of facts. He made free use of inference and conjecture, and above all he imposed upon the good faith of listeners who undoubtedly had a high regard for his veracity.

In summing up, it appears that the portions of Conkling's argument which rest upon quotations from the Journal of the Joint Committee by no means sustain the impressions he drew. The whole argument, in fact, is found to be little better than a shell of inference built up in the course of attempted proof of inconsequential points. Not one but both of his major propositions collapse under weight of facts which he himself cited. Misquotation, equivocal statements, and specious distinctions suggest an inherently weak case - even point toward deliberate fabrication of arguments. All in all, the showing is so poor that one is forced to consider whether Conkling's personal reputation, and the advantage which he enjoyed as the first member of the Joint Committee to produce and make use of the Journal, did not account to large extent for his contemporary success, whereas the continued credence given his argument has been the result of these factors plus the natural tendency for tis today to assume foresight in those matters which are reasonably clear to hindsight, it heing forgotten that as applied to historical interpretation this is often an unwarranted - even dangerous - assumption.

Practically, the only point in Conkling's argument not so far discredited is his statement that "at the time the Fourteenth Amendment was ratified, joint stock companies were appealing for congressional and

45. There is the important difference, however, that Conkling undoubtedly had a strong motive for misleading the Supreme Court, whereas the chief question must always be whether Bingham had any motive for desiring to aid corporations. 
administrative protection against invidious and discriminating State and local taxes. One instance was that of an express company whose stock was owned largely by citizens of the State of New York . . " "40 This is an explicit statement, and one which merits thorough investigation, but it must be stressed that by itself it is scarcely adequate proof of Conkling's point. Corporations may indeed have petitioned the Thirtyninth Congress for relief, but alone this fact proves little. Without direct, contemporaneous evidence that the drafters of the Fourteenth Amendment devised its phraseology with corporations in mind, or at least without evidence that they regarded it as benefiting corporations, once drafted, the existence of these parallel occurrences may have been simply coincidence - a coincidence which Conkling, arguing long after the event and at a time when corporations were moving heaven and earth to broaden judicial interpretation of "persons" and "due process of law," may have shrewdly determined to capitalize. In view of the liberties he appears to have taken with other facts, in view of his temptations to stretch the record ${ }^{47}$ and of his unique opportunities for doing so, ${ }^{49}$ above all, in view of the dangers of relying upon purely circumstantial evidence to establish intent in cases where intent presumes an exceptional viewpoint and perspicacity, one is warranted, at least until it is proved that Bingham had a substantive conception of due process, in regarding this portion of Conkling's argument as essentially immaterial.

\section{The Evidence in the Congressional Debates}

It becomes increasingly apparent that the conspiracy theory can hardly attain satisfactory status until precise knowledge is had of what the framers themselves conceived to be the meaning of the language they employed. Conkling's argument and the circumstantial record of the Journal prove inconclusive and therefore inadequate on this point. It remains to assay the evidence which is found in the congressional debates of 1866.

The impressive thing here, of course, is the utter lack of contemporaneous discussion of these clauses which are today considered all-important. Hundreds of pages of speeches in the Congressional Globe contain only the scantest reference to due process and equal protection. ${ }^{10}$

46. See supro note 22 .

47. I.e., as a lawyer anxious to see the Supreme Court "liberalize" the Fourteenth Amendment, particularly to the extent of declaring corporations "persons."

48. I.e., as a man high in public life relating inside history for the first time, and bolstering his case-or shall we say his inferences-by citations from a manuscript journal not heretofore known to exist.

49. Aside from the Bingham speeches cited supro in note 6, the most important references to these clauses were in speeches by Reverdy Johnson, Democratic Senator from Maryland and minority member of the Joint Committee [Coxc. Grose, 39th Cong., 
Two opposing explanations will perhaps be offered in this connection. Critics of the conspiracy theory will doubtless hold that dearth of discussion indicates a universal understanding that these clauses were to protect the freedmen in their civil rights. Sponsors, on the other hand, may argue that silence indicates a universal misunderstanding of what were in fact the "real" purposes of the framers.

It is desirable because of this double-edged character of the argument from silence, and because of the peculiar dangers inherent in its use as a proof of "conspiracy," that we digress a moment at this point in order to avoid later confusion.

So long as intent or design is one major element in any conspiracy, and so long as silence or secrecy is the other, it readily follows that if the framers of the Fourteenth Amendment intended to benefit corporations, and yet failed to make known their intentions - which otherwise were not suspected - then the framers were guilty of conspiracy. In short, intent plus silence in a situation of this kind equals conspiracy. When this formula is applied to the present case, it follows further, since the fact of silence is not questioned, ${ }^{50}$ that the actual intent of the drafters to afford corporations relief is the only point at issue. To prove intent is to prove the conspiracy theory. But it is precisely at this point that confusion arises. Since silence, along with intent, is one of the

1st Sess., (1866) 3041]; J. B. Henderson, Republican Senator from Missouri [Id, at 3035-3036]; Jacob M. Howard, Republican Senator from Michigan and majority member of the Joint Committee [Id., at 2766]. However, even these references are so brief as to settle nothing. Reverdy Johnson favored the due process clatuse but opposed the privileges and immunities clause "simply because I do not understand what will be the effect of that," inferring, of course, that he thought he understood what was to be the effect of due process. The only fragment of evidence in the Globe suggesting that Johnson may have had a substantive conception of due process is that on one occasion when debating the constitutionality of test oaths - i.e., not when discussing due process-[Cong. Globe, 39th Cong., 1st Sess. (1866) 2916] he alluded to the Alabama case In re Dorsey [7 Port. 293 at 296 (1838)] in which Justice Ormond had held a duelling test oath to be a violation of the due course of law clause of the Alabama Constitution. This would seem to be too slender a reference to serve to link these two concepts.

The speech of Senator Henderson is more suggestive, particularly in the light of our later discoveries regarding Bingham's views. Henderson obviously regarded the whole of Section 1 as applying only to Negroes, for he criticized it as unnecessarily prolix and declared that the whole problem would have been solved by a draft prohibiting the States from discriminating against Negroes because of race or color. However, he did regard "life, liberty, and property as absolute inalienable rights" and was thus probably prepared to read into the clause his personal conceptions of justice - even though his discussion implied that he regarded the due process phrase as properly securing only notice and hearing, etc.

Howard's speech is consistent with a "Negro race interpretation" of Section 1.

50. That is, one searches the debates in Congress and in the ratifying legislatures in vain for any intimation to the effect that the Fourteenth Amendment afforded prospective relief to corporations. 
major elements of conspiracy, there is a natural tendency to use it not only to prove the theory, but also, by a confusion of purposes and ideas, to prove intent. This is done generally in the roundabout fashion of assuming that silence is evidence of secrecy, and that secrecy in turn is evidence of intent. It is hardly necessary to point out that this is a chronic form of circular reasoning which amounts practically to using the argument from silence as a screen to mask the assumption of what one is really trying to prove. Logically, it is a pitfall which one must take particular care to avoid. Intent to aid corporations must be proved by satisfactory evidence and not derived or assumed from the mere fact of silence.

Turning now to an examination of the evidence in the Globe, it can be said that the speeches of Bingham ${ }^{51}$ alone are really suggestive and worthy of. analysis, although even they are found deficient in essential particulars. Stripping Bingham's arguments down to their vital points, one may list the following, particularly in their cumulative effect, as more or less favorable to the conspiracy theory:

1. Bingham deemed it to be a grave weakness that the entire Bill of Rights of the Federal Constitution and more particularly the due process clause of the Fifth Amendment applied only as a restraint upon Congress. Holding citizenship to be national and denying, therefore, that the States had ever rightfully been able to interfere with the privileges of national citizenship - among which were the fundamental rights of life, liberty and property ${ }^{52}$ - Bingham's first consideration was to devise an amendment which would remedy this defect. ${ }^{53}$ It can be said with assurance that to do this was the general purpose of all his various drafts,

51. See supra note 6 . It should be stated at this point that Bingham nowhere defined what he meant by "due process of law." However, the following exchange took place in the course of one of his speeches:

Mr. Rogers . . . "A question. I . . . wish to know what you mean by "due process of law'."

Mr. Bingham, "I reply to the gentleman, the Courts have settled that long ago; and the gentleman can go and read their decisions."

Cowg. Grose, 39th Cong. 1st Sess. (1866) 1059. One might say in 1937 that Bingham was somewhat deceived as to the "settled" character of his doctrine.

In the peroration of this same speech Bingham spoke of "due process of lawlaw in the highest sense, that law which is the perfection of human reason, and which is impartial, equal, exact justice; that justice which requires that erery man shall have his right; that justice which is the highest duty of nations as it is the imperishable attribute of the God of nations."

52. A view which derived from Justice Washington's dictum in Corfield v. Corgell, 6 Fed. Cas. No. 3, 230 (E. D. Pa. 1823). See Howeur, Pammeges aro Iznromities of State Cittzenship (1918) 19.

53. This point, which recurs in Bingham's speeches, is best developed in that of Feb. 28, 1866, Cong. Globe, 39th Cong., 1st Sess. (1866) 10S9-1090. 
including the early forms which provided "Congress shall have power to ... secure to all persons in every State equal protection in the rights of life, liberty and property." A desire to curb the States, to nationalize fundamental rights, and to do this using the phraseology of the Fifth Amendment, were the hubs around which Bingham's thinking revolved ${ }^{54}$

2. Bingham was emphatic at times in pointing out that the Fourteenth Amendment did not apply merely to the Southern States and to the Negroes. "It is due to the Committee," he declared on one occasion" when asked whether his draft "aimed simply and purely toward the protection of American citizens of African descent," "that I say it is proposed as well to protect the thousands and tens of thousands and hundreds of thousands of loyal white citizens of the United States whose property, by State legislation, has been wrested from them by confiscation, and to protect them also against banishment . . . It is to apply to other States also that have in their constitutions and laws today provisions in direct violation of every principle of our Constitution." Asked at this point whether he referred to "the State of Indiana," replied, "I "I do not know; it may be so. It applies unquestionably to the State of Oregon." These allusions are obviously in harmony with' some explicit and definite purpose.

3. Likewise suggestive of catholic motive, and of one somewhat in line with Conkling's claims, is the fact that Bingham on one occasion ${ }^{68}$ sounded out congressional sentiment in favor of an "added . . . provision that no State in this Union shall ever lay one cent of tax upon the property or head of any loyal man for the purpose of paying tribute and pensions to those who rendered service in the .. . atrocious rebellion . . . I ask the gentlemen to consider that, as your Constitution stands today, there is no power, express or implied, in this Government to limit or restrain the general power of taxation in the States."

4. At one point in his argument Bingham referred," though very casually, to the decision of the United States Supreme Court in "the great Mississippi case of Slaughter and another." Unquestionably this reference was to the slavery case of Groves $v$. Slanghter, ${ }^{\mathrm{co}}$ decided by the Court in 1841. As such, it is a reference of great potential importance for the reason that Justice Baldwin, an ardent defender of slavery, anxious to place that institution beyond the control of both the States

54. For a more detailed analysis of the framers' purposes, see FLACK, op. cit. supra note 4 , at $68-69,81-82,94-97$.

55. Speech of Feb. 27, 1866. Cong. Globe (1866) 1064-1065.

56. Ibid. The question was put by Rep. Hale, Republican, New York.

57. Ibid.

58. Cong. Globe, 39th Cong., 1st Sess. (1866) 429.

59. Speech of Feb. 28, 1866, id., at 1094.

60. 15 Pet. 449 (U. S. 1841). 
and the Federal Government, had here, for the first time, used the due process clause of the Fifth Amendment as a means of restraining Congress' power over slaves in interstate commerce. ${ }^{01}$ Baldwin's opinion thus applied due process in a definitely substantive sense, and it anticipated by fifteen years Chief Justice Taney's similar application in the case of Dred Scott.

A fact which seems to heighten the importance of Bingham's mention of Groves v. Slanghter is that in a later part of his dictum Justice Baldwin had used the comity clause (Article IV, Section 2) as the means of withdrawing the slave traffic from State control. ${ }^{02}$ In short, Baldwin used both of the identical clauses which Bingham and the Joint Committee eventually included in Section One. The question necessarily arises, therefore, whether Bingham may not have taken his cue from Baldwin - whether, as a means of protecting all property, including of course the property of (former) slaves, he did not deliberately build upon and strengthen the No Man's Land which Baldwin originally had created for the protection of property in slaves. For a Radical Republican to have done this would have constituted a great tactical triumph, in any event, and one can readily see how, if Bingham actually sought to protect foreign corporations in the manner Conkling intimated, the stroke would have amounted to positive genius. For, clearly, in addition to strengthening the barriers of that No Man's Land which-according to Justice Baldwin at least - existed in the original Constitution with regard to property per se, Bingham created still another No Man's Land which surrounded and protected the "persons" who owned property. He did this simply by making the due process clause - one half of Baldwin's original system of protection - itself a restraint upon both the Federal Government and the States. "Persons" in consequence were thus secured in their rights of property, against both Congress and local legislatures.

What is one to conclude from the discovery that John A. Bingham, author and sponsor of the equal protection-due process phraseology, (1) aimed to secure greater protection in the fundamental rights of property; (2) intended to curb all states, including Oregon; (3) desired an "added provision" limiting the taxing power; (4) cited a case wherein substantive use had been made of due process to protect property rights; (5) even used the identical clauses in Section One which Justice Baldwin had used in this early substantive opinion?

The first point to note in answering this question is that only when one places the most favorable interpretation upon each individual part of the evidence does the whole, taken collectively, suggest that Bingham

61. Id., at 514. For the historical importance of this dictum, see Conwn, CorssTerce POWER VERsus States' Rights (1936) 70-71.

62. 15 Pet. 514-516 (U.S. 1841). 
may have had the purpose which Conkling intimated in his argument. A moment's examination, however, reveals numerous points at which the evidence is inadequate to support these separate conclusions. Three in particular may be cited:

1. Bingham simply declared himself in favor of an additional provision limiting the taxing power. One cannot determine from his speeches whether he regarded his own draft as having the effect of limitation or whether he simply meant to sound out sentiment in favor of a draft which would have this effect. ${ }^{63}$ Obviously one must not infer the former motive from silence alone, without other evidence.

2. Bingham mentioned no particular opinion when referring to Groves i. Slaughter; ${ }^{64}$ he simply inferred that the case had decided that "under the Constitution the personal property of a citizen follows its owner, and is entitled to be protected in the State into which he goes." While these words might be construed as a reference to the comity clause portion of the Baldwin dictum, ${ }^{65}$ the conservative course is to draw no conclusion from such meager circumstances.

3. It will be noted that Bingham justified his draft on the grounds that it protected "loyal white citizens" and "any loyal man" as well as Negroes. In short, his references are all to natural "persons," never to artificial ones. ${ }^{66}$ Granted that a hidden motive would undoubtedly have

63. Bingham's only reference to the need for a curb on the taxing power was made in a speech delivered January 25, 1866. Cong. Globe, 39th Cong., 1st Sess. (1866) 429. The day previous the Joint Committee had voted to remove the injunction of secrecy [KENDRICK, op. cit. supra note 4, at 56] in order that members might "announce the substance and nature of the proposed amendment" in their speeches on the floor. When this fact is kept in mind, the order and substance of Bingham's remarks suggest that his speech was in the nature of a trial balloon designed to test the sentiment in the House.

64. Failure to mention an opinion is important for the reason that the Court in this case split six ways, with four opinions. Baldwin alone mentioned due process. See Swisher, Roger Brooke Taney (1936) 396-399 and 2 Warren, The Supieme Court in United States History (1923) 340-347, for details of this case which in many respects was prophetic of the Dred Scott decision.

65. 15 Pet. 449, 515 (U.S. 1841).

66. Bingham's most explicit statement pertaining to the word "person" was made in the course of a speech on the Civil Rights bill on March 9, 1866 [CoNG. Grone, 39th Cong., 1st Sess. (1866) 1292]. Objecting that the bill as then drafted applied only to "citizens," and therefore discriminated against aliens, Bingham declared: "The great men who made that instrument, [the United States Constitution] when they undertook to make provision, by limitations upon the power of this Government, for the security of the universal rights of man, abolished the narrow and limited phrase of the old Magna Charta of 500 years ago, which gave the protection of the laws only to 'free men' and inserted in its stead the more comprehensive words 'no person'; thereby obeying the higher law given by a voice out of heaven: 'Ye shall have the same law for the stranger as for one of your own country'. Thus in respect to life and liberty and. property, the people by their Constitution declared the equality of all men, and by 
impelled secrecy with reference to corporations, it is still true, as we have already pointed out, that secrecy is not here admissible as a proof of intent.

The chain of circumstances from which intent might be deduced thus being broken at several points, it is plain that the evidence in Bingham's speeches is not adequate proof of the conspiracy theory. It remains to linger a moment at this point, however, in order to note several features of his argument.

First of these features is a very important implication of his statement that his phraseology was designed to protect, not merely Negroes, but "the thousands ... of loyal white citizens of the United States whose property, by State legislation, has been wrested from them by confiscation, and to protect them also against banishment. It is to apply to other States also that have in their constitutions and laws today provisions in direct violation of every principle of our Constitution." ${ }^{\text {"67 }}$

The fact that intrinsically this statement suggests that natural persons were the only objects of Bingham's solicitude must not be permitted to obscure the significance of the type of legislation which had offended him. Laws enacted during and after the Rebellion by the eleven "rebel" and apparently by a few "other States," laws which inflicted "banishment" and "confiscation" upon "loyal white citizens" were the particular objects of his ire. Such laws, in his judgment, violated "every principle of our Constitution" and in giving Congress power to "secure to all persons equal protection in the rights of life, liberty and property," he doubtless meant to extirpate these abuses.

The point which we here wish to stress is that this motivation practically assures - so long as Bingham appears to have associated "equal protection" with "due process of law" - that he had a substantive conception of due process. It is hardly conceivable, at any rate, that a Radical Republican, outraged by acts of rebel confiscation - which he regarded simultaneously as denials of equal protection and due process of law - objected to this confiscatory legislation simply because it denied such traditional requirements of due process as fair notice and hearing. Inherently the circumstances suggest that it was the substance of such legislation, not merely its effects upon the procedural rights of the ac-

express limitation forbade the Government of the United States from malsing any discrimination.

"This bill, sir, . . . departs from that great law. The alien is not a citizen. You propose to enact this law . . . in the interests of the freedmen. But do you propose to allow these discriminations to be made in States against the alien and stranger? Can such legislation be sustained by reason or conscience? . . . Is it not as unjust as the unjust State legislation you seek to remedy? Your Constitution says 'no person,' not 'no citizen,' 'shall be deprived of life, liberty, or property, without due process of law."

67. See supra note 55. 
cused, that one invoking the clause would have attacked. Stated otherwise, circumstances point to a "natural rights" usage, and a natural rights usage is here obviously a substantive one. ${ }^{68}$

By a somewhat indirect and unexpected turn, one thus discovers evidence which indicates that Bingham in 1866 probably did have a substantive conception of due process of law, and did, therefore, regard the guarantee in a manner which was potentially of benefit to corporations. Paradoxically, however, the importance of this discovery is minimized, so far as its bearing on the conspiracy theory is concerned, by its own implications. Bingham used due process in a natural rights sense. He read into the clause his personal conceptions of right and justice. But the very circumstances under which he did this point to the existence of an intense and specific motivation which may very well have so absorbed his energies and interests that he gave little or no thought to the auxiliary uses of his phraseology. If one adopts this view, Bingham was a Radical Republican consumed by a determination to thwart those "rebels" and Democrats who were inclined to vent their animosity by discriminating against negroes, loyalists, "carpetbaggers," etc. He was a crusading idealist, and it is an open question whether he was not, for this reason alone, one of the persons least likely to ponder the needs and constitutional status of corporations. A zealot is rarely so ambidexterons.

It is a merit of this simple discovery relating to Bingham's pur * poses that it leads to an hypothesis which can be readily and profitably checked. If Bingham regarded due process of law in a natural rights* substantive sense; if he conceived certain laws enacted by rebel and "other States" as violating "every principle of our Constitution," then conceivably, he may have outlined his views in earlier speeches in Congress. Particularly so long as the problems dealt with in these Reconstruction debates are known to have extended far back in the pre-war controversies over slavery, it is logical to expect that Bingham, a highly articulate leader who served in Congress almost continuously beginning in 1854, expressed himself freely on these matters, and that his speeches thus record the evolution and content of his thinking. Obviously it is an easy matter to inspect his speeches with an eye for clues to the origin, development, and significance of his concepts of due process and eqtal protection.

Bearing in mind the mystery of the declaration that his draft applied "unquestionably to the State of Oregon," and bearing in mind also the ambiguity of his allusions to the "great Mississippi case of Slaughter and another," and to the need for curbing the taxing power of the States, we can now make an investigation of this kind.

68. Confirmation of Bingham's substantive conception of due process is found in his speech of March 9, 1866, on the Civil Rights Bill [see supra note 66] and in his speech of Feb. 28, 1866 [see sitpra note 51]. 


\section{Binghan's Conception of Due Process of LAw, 1856-1866}

Three major speeches are found which shed light on these important matters. In $1856,{ }^{69}$ in $1857,7^{70}$ and again in 1859,71 Bingham outlined views which not only clear up the obscurities we have noted in his later speeches but which go far toward solving the deeper problems of his motivation. Carefully checked, these three speeches reveal that Bingham did in truth conceive of due process as a limitation upon the substance of legislation - that he so conceived it as early as 1856 . Yet they give no indication that he regarded corporations as "persons," nor do they indicate that his use of the due process clause was inspired by any solicitude for corporate rights. On the contrary, it appears that Bingham in his third speech in 1859 cited the due process clause of both the Fifth Amendment and the Northwest Ordinance, together with the comity clause - in short, the very clauses which seven years later he used in his final draft of Section One - as having been violated by a section in the Oregon Constitution ${ }^{72}$ which provided:

"No free negro or mulatto not residing in the State at the time of the adoption of this Constitution, shall ever come, reside, or be within this State, or hold any real estate, or make any contract, or maintain any suit therein ..."

This evidence obviously suggests that free Negroes and mulattoes natural "persons," rather than corporations - were the original objects of Bingham's solicitude. As his speeches and drafts in 1866 give evidence of having been based upon his speech of 1859, the question necessarily arises whether Negroes rather than corporations were still the sole objects of his concern at the later date.

Read in their social and historical context, Bingham's speeches not only reveal how he came to focus upon the due process clause, but how he came to read into it this revolutionary substantive meaning. It was on March 6, 1856-exactly one year before Chief Justice Taney's opinion in the Dred Scott case - that Bingham, making his maiden speech in the House, ${ }^{73}$ argued that laws recently enacted by the Kansas

69. Cong. Globe, 34th Cong., 1st Sess. (1856) Appendix, at 124.

70. Cong. Globe, 34th Cong., 3rd Sess. (1857) Appendix, at 135-140.

71. Cong. Giobe, 35th Cong., 2nd Sess. (1859) 981-985.

72. Article I, Section 35, Constitution of Sept. 18, 1857.

73. See supra note 69. The Kansas Territorial Legislature, dominzted by the proslavery forces and acting under a pro-slavery Constitution, had adopted verbatim the drastic Missouri slave code which inter alia (quoting Bingham) made it a felony "for any free person, by speaking or writing, to assert that persons have not the right to hold slaves in said Territory." Bingham contended that these provisions abridged "the freedom of speech and of the press as well as deprived persons of liberty without due process of law." The text of the Kansas law is given in SEs. Exac. Doc, No. 23, 34th Cong., 1st Sess. (1856) 604-606. 
(Shawnee Village) legislature, declaring it a felony even to agitate against slavery, deprived "persons of liberty without due process of law, or any process but that of brute force." As this speech was delivered just two weeks after the Supreme Court's decision in the major case of Murray v. Hoboken Land and Improvement Company, ${ }^{74}$ wherein counsel in arguing procedural questions had cited such germinal substantive cases as Hoke $v$. Henderson ${ }^{75}$ and Taylor v. Porter, ${ }^{76}$ and wherein Justice Curtis had distinguished in his opinion between legal process and due process with regard to procedure, ${ }^{77}$ the presumption is that Bingham, seeking for a constitutional clause on which to hang his political and ethical opinions, appropriated Curtis' distinction and carried it over from procedure to substance. The fact that the Kansas laws had simply defined the felonies, and had not interfered with the procedural rights of the accused, makes it plain that Bingham's citation could have been made only in a substantive sense. ${ }^{78}$

The character and circumstances of Bingham's original application of the due process clause raise the question of whether he could have been the first - or among the first - to employ it as a weapon in the slavery debates, and whether, accordingly, his action did not in some manner determine the Republican Party's heavy reliance upon "due process of law" just three months later in its platform of $1856 .{ }^{\mathbf{7 0}}$ Satisfactory answers to these two questions must necessarily wait a careful search of voluminous records, but meanwhile several fragments of evidence point in Bingham's direction: (1) Bingham was colleague and protege of Joshua Giddings, abolitionist Congressman from Ohio who in 1856 served as an influential member of the Republican platform committee, and who drafted the planks in which the due process clause

74. 59 U. S. 272 (1856). This case was argued Jan. 30, 31, Fcb. 1, 4, 1856, and decided Feb. 19, 1856.

75. 15 N. C. 1 (1833). Professor Corwin stresses the significance of this case in his article cited supra note 14 , at 383 .

76. 4 Hill 140, 146 (N. Y. 1843). This case is famous as the first in which the New York Courts began employing the due process clause of the State constitution as a means for absorbing the doctrine of vested rights. See Corwin, Growth of Judicial Review in New York (1917) 15 MicH. L. Rev. 297.

77. 59 U. S. 272 , at 276 (1856).

78. See Bingham's own paraphrasing of these in his speech. Cong. Grone, 34th Cong., 1st Sess. (1856) Appendix, at 124. See supra note 73 for one example.

79. The plank on Slavery in the Territories, drafted with particular reference to Kansas, declared that "our Republican Fathers, when they ... abolished slavery in all .. . national Territory, ordained that no person shall be deprived of life, liberty, or property without due process of law; it becomes our duty to maintain this provision against all attempts to violate it for the purpose of establishing Slavery in the Territories of the United States by positive legislation ..." In a later passage the people of Kansas were cited as having been "deprived of life, liberty and property without due process of law." See Procendings of the First Three Republican Conventions of 1856, 1860, AND 1864 (1893) 43. 
appeared. $^{80}$ (2) While Giddings is known to have made use of due process in his speeches after $1856,{ }^{81}$ the writer has found no instance of his having done so earlier, ${ }^{82}$ thus suggesting that Bingham's usage antedated Giddings', and that it may, therefore, even have inspired it. (3) Philomen Bliss, another Republican and Ohio colleague of Bingham in the 34th Congress, is known to have used the due process clause in several speeches in 1856 and $1857,,^{83}$ but in each instance it was after a similar usage by Bingham. Bingham therefore is the earliest known user, and this fact, together with his persistence, and the apparent tendency for the early usage to center in the Ohio delegation, suggests that he may well have been the evangel of due process in the modern substantive sense.

Evidence indicates that Bingham, having discovered due process of law, explored it thoroughly, perceived something of its rhetorical possibilities as a weapon in the anti-slavery debates, noted that it had been included in the Northwest Ordinance of $1787,{ }^{84}$ and read into the vague

80. Id., at 22. Julian states, [The LIFE of JoseuA R. Grodrics (1892) 335-6] "By far the most important part of the platform was written by Giddings in his library at Jefferson and is here copied," and then quotes the entire plank relating to Slavery in the Territories.

81. See Cong. Grobe, 35th Congress, 2d Sess., 346 (1859).

82. Giddings' Sperches iN CoNGress, published in 1853, reveal that throughout his long career as an Abolitionist leader in the House he relied on the Declaration of Independence as a secondary constitution, citing the phrase "inalienable rights of life, liberty and the pursuit of happiness" again and again. Yet no mention is found of due process of law either in these speeches or in those between 1852 and 1856 in the Corgressional Globe.

83. Cong. Globe, 34th Cong., 1st Sess. (1856) Appendix, at 553-7. Speaking two and a half months after Bingham, and on the eve of the Republican convention, Bliss leaned heavily on stock natural rights arguments, and cited the due process clause in several places. Even more suggestive of Bingham's influence is Bliss' speech of Jan. 15, 1857 (two days after Bingham's speech of Jan. 13). Cowc. Grode, 34th Cong., 3d Sess. (1857) Appendix, at 145, 149. Here Bliss cited constitutional history and emphasized that the framers of the Bill of Rights substituted "person" for "frecmen," etc.

See the speech of Rep. A. P. Granger of New York, [Cosc. GLode, 34th Cong., 1st Sess. (1856) Appendix, at 295-7] April 4, 1856, four weeks after Bingham's first speech. This is the earliest known speech, aside from Bingham's, that employs due process of law in argument and the only one which the writer has been able to find made by a non-member of the Ohio delegation.

84. The significance of this fact is that Congress in organizing Territories and passing enabling acts for the creation of new States frequently stipulated that these new local constitutions be "not repugnant to the Northwest Ordinance of 1787." Thus one could argue that while the due process clause of the Fifth Amendment applied only as a restraint upon Congress, the law of the land clause of the Northwest Ordinance had nevertheless been made a restraint upon these particular States. This idea seems to have been implicit (if not always clearly stated) in Bingham's arguments, and it was apparently one means of his getting round the embarrassing features of John Marshall's opinion in Barron v. Baltimore [7 Pet. 243 (U. S. 1833)]. The speech on the President's Message in 1857 lays considerable stress on the Northwest Ordinance, even quoting Taney's opinion in Strader v. Graham [10 How. 82 (U. S. 1850)]. 
outlines of the phrase all the fervent idealism of a natural rights philosophy. Thus, in his second speech, ${ }^{85}$ delivered on January 13,1857 , (still six weeks before the Dred Scott decision) one finds him emphasizing repeatedly that the clause applies to all "persons," not merely to all "citizens;" that "it protects not only life and liberty, but also property, the product of labor;" that "it contemplates that no man shall be wrongfully deprived of the fruit of his toil any more than his life." In this speech also, Bingham alludes to the case of Groves v. Slanghter - albeit to McLean's, not Baldwin's opinion ${ }^{86}$ and in it too he makes clear that the "absolute equality of all and the equal protection of each" are the great constitutional ideals of American government and as such "ought to be observed and enforced in the organization and admission of new states." In point of fact, Bingham declared they were enforced: It was for this very reason that "the Constitution . . . provides that no person shall be deprived of life, liberty or property without due process of law," and that it made "no distinction either on account of complexion or birth."

In short, this second speech, likewise made with reference to the power of Congress to regulate slavery in the Territories, reveals a progressive development of ideas and a more thorough study of Constitutional history. ${ }^{87}$ One concludes that while Bingham still applied the due process clause only with reference to natural "persons," he none the less increasingly thought of it as extending protection in accordance with his views of right and justice. Moreover, his political idealism, expressed in the "equal protection" concept, and strongly infused with natural rights philosophy, provided a reservoir of ethical and moral judgments which

85. See supra note 70 .

86. Bingham's use of Justice McLean's opinion deserves comment. Having argued that due process "contemplates that no man shall be wrongfully deprived of the fruit of his toil," Bingham had obviously laid himself open to exactly such use of the clause as Chief Justice Taney (then engaged in writing his opinion) was presently to make in the Dred Scott case. There is reason to believe that Bingham was conscious of this weakness, for it was in this connection that he quoted McLean's opinion: slaves were not property under the Constitution; "The character of property is given them by the local law . . . the Constitution acts upon slaves as persons, and not as property." One must immerse himself deeply in anti-slavery polemics to follow the logic of this distinction, but once the premises are granted, it is plain how due process was to be made a bulwark for slaves and abolitionists, but not for their masters. The sole difficulty, apparently, was that Chief Justice Taney was not convinced.

87. Specifically it shows (1) a growing awareness that the due process clause specified (a) "no person" and (b) "property" in addition to "life and liberty," (2) a conviction that this meant "no man shall be wrongfully deprived of the fruits of his toil," (3) a formulated concept of "equal protection"-the very phrase which Bingham was later to use in the Fourteenth Amendment-as the lofty ideal of American government, and as the corollary, if not merely the equivalent, of due process of law. The genesis of the equal protection concept is of extraordinary interest, particularly in view of its association with due process of law. 
one might logically expect to find their outlet through the due process phrase.

It is exactly this tendency that one notes in Bingham's third speech, ${ }^{83}$ delivered February 11, 1859, with reference to the above-quoted "no free Negro or mulatto" clause in the Oregon Constitution. Secling constitutional sanction for his anti-slavery views, Bingham again and again relied upon "natural and inherent rights," on "sacred rights . . . as universal and indestructible as the human race," on "equality of natural rights," etc., as the cornerstone of his argument. Nor was this reliance without profound significance. Again and again he maintained that "these natural and inherent rights which belong to all men irrespective of all conventional regulations are by this Constitution guaranteed by the broad and comprehensive word 'person,' as contradistinguished from the limited term 'citizen,' as in the Fiftl Article of Amendments." ${ }^{83}$ The due process clause, in short, was the repository of natural rights. Adding to the significance of this natural rights usage of due process, and illuminating the pressures that inspired it, is the fact that while no other member of Congress appears to have used the clause as Bingham did, a number nevertheless relied heavily on extra-Constitutional natural rights arguments in defending or condemning the provision in the Oregon Constitution, ${ }^{90}$ and at least one member attempted to use the "Republican form of government" clause in exactly the manner which Bingham used due process. ${ }^{01}$ Obviously these circumstances suggest that Bingham's tendencies were in no way exceptional or extreme; he had simply made a happier choice in his selection of weapons. Whereas the "Republican form of government" wording was probably too ambiguous to invite usage in such cases, the due process phraseology, con-

88. See supra note 71.

89. (Italics not in the original). It is impossible to determine from Bingham's spaech whether he was aware as yet of the decision in the case of Barron 2 . Ballimore [7 Pet. 243 (U. S. 1833)] wherein John Marshall had declared the first eight amendments to be restraints on the Federal Government, not on the States. In 1866 this decision served as the cornerstone for Bingham's whole argument, and he cited Marshall's opinion again and again. However, the fact that his speeches in the fifties all concerned the constitutional rights of persons in the Territories, not in the States, and the further fact that the Northwest Ordinance (with its law of the land clause) had generally been made binding on the Territories at the time of their organization, may partially explain Bingham's silence regarding the Barron decision at the carlier date. He may simply have assumed that whatever the status of due process in the States, the Northwest Ordinance clauses applied in the Territories.

90. See, e.g., the very interesting speech of Rep. Hourd [Cosc. Grone, 35th Cong., 2d Sess. (1859) 987] in which he said, "Is it not manifestly unjust to deny any freeborn American, guilty of no crime, the right of home in the land of his fathers? If it is admitted, as I think it must be, that such denial is unjust, then it is unconstitutional." Here surely is evidence of how strongly in need men were of some clause to give constitutional sanction to their ethical and political opinions.

91. Id., at 952 (Rep. Granger). 
taining the all-embracing terms "life," "liberty," and "property," and containing also the word "due," one synonym of which is "just," was ideally suited both for application and expansion.

One finds in this third speech also an explicit and significant clue to the type of protection which Bingham conceived. Who would be "bold enough to deny," he demanded, "that all persons are equally entitled to the enjoyment of the rights of life, liberty and property; that no one should be deprived of life or liberty but by punishment for crime; nor his property, against his consent and without due compensation." ${ }^{02}$

This telescoping and virtual rewriting of the due process and just compensation clauses necessarily afford valuable insight into Bingham's mind. It is probably to be expected that anyone using these clauses in a natural rights sense will use them loosely; yet three aspects of the constitutional status of property as viewed by Bingham must be noted. First, he deems it axiomatic that a man's property must not be taken "without his consent;" property rights by his view are thus virtually absolute. Second, and not altogether surprising in the light of this first proposition, he omits all reference to the qualifying phrase that it is really "for public use .. . " that property is not to be "taken without just compensation." Third, in using "due" as a synonym for "just" in the just compensation clause, it is reasonable to suppose that conversely he may have used "just" as a synonym for "due" in the due process clause; and very likely it was in this manner that a textual factor reinforced the natural rights factor in furthering his substantive conception of due process. Stated somewhat differently, according to Bingham's view, due process probably meant just process, and inherently, therefore, it could never be limited simply to its procedural elements.

All in all, when one considers the scope and possible applications of the phraseology construed in this manner, it is apparent that Bingham from 1859 onward held views - whether he actually applied them or not - which were potentially capable, to use the Beards' phrase, of "taking in the whole range of national economy." Indeed his views are in many respects so much like those expressed by the Justices of the New York court in the revolutionary case of $W$ ynehamer v. People in $1856^{93}$ that one is led to speculate whether Bingham may not have been

92. Id., at 985. (Italics not in original). Here it will be noted that Bingham is thinking (1) only of natural persons, who are, however, to be "equally" protected; (2) of liberty in the physical rather than in the present-day sense.

93. 13 N. Y. 378, 391 (1856). To quote Professor Corwin's analysis: "The main proposition of the decision in the Wynehamer case is that the legislature cannot destroy by any method whatever, what by previous law was property." Op. cit. sutpra note 14, at 468 . Bingham obviously regarded this proposition as axiomatic; for who would deny that "no one should be deprived of . . . his property against his consent and without due compensation?" 
familiar with the dicta of those opinions. It seems significant at any rate that his own views should so closely parallel those which others, elsewhere, were applying to the defense of business interests then contending against legislative regulation.

Two additional points must now be noted. The first is that judging by the similarity of numerous passages of rhetoric and statements of fact, the Oregon speech of 1859 appears to have served as an important source and reference in the preparation of his arguments and drafts in $1866 .^{94}$ This fact alone suggests a close link between the Fourteenth Amendment phraseology and the Oregon "no free Negro and mulatto" provision.

The second point, more or less implicit in foregoing quotations, is that several times in the course of this argument in 1859 Bingham made clear that he regarded the just compensation clause, no less than the due process clause, as a bulwark of natural and "sacred rights which are as universal and indestructible as the human race." The significance of this fact will be apparent when one recalls that Bingham's attempt to secure inclusion of a just compensation clause in the Fourteenth Amendment in 1866 has always been regarded as one of the strongest indications of an intent to aid business and corporations and thus to "take in the whole range of national economy." Now, however, it develops that he cited this same clause seven years earlier in the speech which, as we have just pointed out, appears to have been an important source of his later remarks, and which was indubitably inspired by discriminations against free Negroes and mulattoes.

Finally, perhaps the most significant thing about Bingham's Oregon speech is that he here made use, in addition, of the comity clause in order to guarantee the rights of the free Negroes and mulattoes. ${ }^{05} \mathrm{He}$ was able to do this because native-born Negroes and mulattoes, by his comprehensive anti-slavery definitions of citizenship, were "citizens" as well as "persons." 96

94. Thus, in his Oregon speech in 1859 [CoNc. Groge, 35th Cong., 2d Sess. 982] Bingham quoted from Story, Rawls, Kent, and the Dred Scolt opinions to bolster his definitions of citizenship. In his first speech delivered on Jan. 25, 1866, he quoted these identical references in the same order and connection. Conc. Grose, 39th Cong., 1st Sess. (1866) at 430.

95. Cong. Grobe, 35th Cong., 2d Sess. (1859) 984-5. Republicans used this clause to attack the Oregon constitutional provisions. See, e.g., speeches by Reps. Granger and Dawes. Id., at 952, 974.

96. Bingham protected free Negroes with the shield of citizenship, but like Lincoln and others of his party he did not at this date approve of granting Negroes equality of social and political privileges. He upheld the right of States to deny free Negroes the franchise, but disclaimed the right to deny them residence, etc. The difference in Bingham's mind was between political and natural rights: "All free persons ... born or domiciled in any free state of the Union are citizens of the United Stztes; and although not equal in respect of political rights, are equal in respect of natural rights." Id., at 985 . 
There were two important corollaries of this proposition so far as Bingham was concerned. First was that those privileges and immunities to which "citizens of each state" were entitled under the comity clause of the Constitution, Bingham interpreted to be the "privileges and immunities of citizens of the United States," so that the clause read: "Citizens of each State shall be entitled to all privileges and immunities of citizens (of the United States) in the several states." 07 This of course was the very view which he held in 1866 and which is known to have prompted insertion of the privileges and immunities clause in Section One. ${ }^{98}$ Second, and more revealing as a clue to his later purpose in drafting Section One, was that according to his view "amongst these privileges and immunities of citizens of the United States" were "the rights of life and liberty and property and . . . due protection in the enjoyment thereof." Thus the due process clause and the comity clause really guaranteed the same rights, but one applied to "citizens," the other to "persons." By using both clauses in this argument, and likewise by using the phraseology of both clauses in the text of the Fourteenth Amendment in 1866, Bingham undoubtedly conceived that he was affording double protection to the " 800,000 " free Negroes and mulattoes from such discriminations as Oregon had put in her State Constitution. The due process clause being the repository of the natural rights of all "persons," and the comity clause the special repository of the natural rights of certain "persons" who were also "citizens," it can readily be seen that in theory Bingham had worked out an ingenious though rather complex system of constitutional protection. ${ }^{100}$

With these facts at hand it is now possible to formulate conclusions regarding Bingham's purposes and to note their bearing on the conspiracy theory. The striking thing is of course that in laying the foundation for conspiracy we have apparently destroyed the superstructure. Secking confirmation for the substantive character of Bingham's conception of due process, we have really found confirmation - or apparent confirmation - of Justice Miller's "one pervading purpose-Negro race" theory of the phraseology of Section One.

97. Ibid. As pointed out supra [note 52]. Bingham's views derived from one possible reading of Justice Washington's dictum in Corfield $v$. Coryell, 6 Fed. Cas. No. 3, 230 (E. D. Pa. 1823).

98. FLACK, op. cit. silpra note 4, at 84-87. See also speech of Senator Howard, a member of the Joint Committee, Cong. GroBE, 39th Cong., 1st Sess. (1866) 2765-66.

99. Cong. Globe, 35th Cong., 2d Sess. (1866), 984.

100. With this insight into Bingham's reasoning, and into early Republican constitutional theory in general, one inclines to moderate the view recently expressed by Professor Grant [The Natural Law Background of Due Process (1931) 31 CoL. L. REv. 56, at 66] that Section One was "miserably drafted." "Too zealously drafted," would seem the juster phrase; like many before and since, Bingham reckoned without the Supreme Court. 
We have found this by discovering that every clause which Bingham used in his drafts in 1866 really dated back from seven to ten years in his speeches, ${ }^{101}$ and was identified, originally, with the problem of slavery in the Territories and with the controversial question of the citizenship of free Negroes and mulattoes. State and territorial provisions denying these last-mentioned "persons" the privileges of residence, and of acquiring property and making contracts, provided Bingham with what may have been merely an apparent economic motivation.

An anti-slavery polemist of the natural rights school, a man who held thoroughly Lockian views concerning the sanctity of property and the rights of all men to acquire it, Bingham hit fortuitously upon due process in 1856 and used the weapon first to protect the "liberty" of abolitionists, then to bolster Congress' power over slavery in the Territories. Chief Justice Taney's application of the same clause with reverse effect in the case of Dred Scott presumably intensified Bingham's convictions and led him farther afield. Eventually the Oregon discriminations caused him to use due process to guarantee to free Negroes as "persons" the very rights which Taney had guaranteed to slave holders as "persons." To clinch this protection, and doubtless to pay his respects to the aged Chief Justice, Bingham maintained that native born Negroes were not only "persons," but "citizens," and not only "citizens," but "citizens of the United States," and as such entitled to be protected by Congress in the enjoyment of their rights of life, liberty and property.

Four observations may now be listed:

1. Apart from its direct bearing on the conspiracy theory, this evidence illuminates the forces which brought about a revolutionary expansion of due process in America. The strong natural rights strain in our political thinking, ${ }^{102}$ and the Lockian view of property as sacred and absolute, ${ }^{103}$ have often been emphasized in this connection. To these, apparently, should be added the intrinsic advantages of the due process phraseology itself and the role of the slavery debates in acting as a powerful flux in welding together these diverse elements. The irresistible urge to find constitutional sanction for ethical and political opinions relating to slavery led both sides to employ the clause in a substantive sense. Perhaps but for the boomerang effect of Taney's usage in the Dred Scott case, due process might have undergone a much earlier and more rapid expansion.

101. That is, the comity, due process, equal protection, and just compensation forms were all employed in these early debates. They were likewise employed in the rarious drafts of Section One, the just compensation clause unsuccessfully. See supra note 8.

102. See particularly Grant, loc. cit. supra note 100; and for an exhausthe general treatment see Haines, The Revival of Naturar Law Concepts (1930).

103. Hamilton, Property-According to Locke (1932) 41 Y ALE L. J. 864. 
2. A natural rights philosophy and an aversion to the spread of slavery, rather than any profound insight into the potentialities of due process, apparently provided the driving force in Bingham's usage. So far as one can judge he was originally a zealot, not a schemer, an antagonist of slavery, not a protagonist of due process and judicial review. The indications are even that like many polemists he was singularly blind to the broader implications of his stand; for during these years he was one of the sternest critics of the Supreme Court ${ }^{104}$ and at the same time the advocate of doctrines which implied a tremendous expansion of its powers. Taken alone, this fact is obviously hard to reconcile with the view that an anti-democratic philosophy and a desire to curb popular control of property in general lay deep in Bingham's consciousness.

3. Section One of the Fourteenth Amendment may be explained in its entirety by assuming that Bingham's purposes in 1866 were similar to his purposes in 1859. Phraseology which has heretofore been abstruse, mysterious, "cabalistic," is thus rendered plausible without imputing to Bingham a desire to include corporations or to "take in the whole range of national economy."

4. While this is true, one must recognize that Bingham's views of "property" and "due process of law" were such that it would have been perfectly natural for him, had occasion ever arisen, to have applied that guarantee to protect the property of corporations. The fact that as a lawyer he spoke and thought of corporations as legal "persons" and that in professional practice he was concerned with their protection, only makes this possibility the more real.

\section{ConCLUSION}

If these facts point to no positive conclusion, they do at least permit one to define more accurately the possible limits of "conspiracy" and to restate its essential conditions.

Stated as concisely as possible, the question henceforth would seem to be whether Bingham in the seven years between 1859 and 1866 came to realize the full potentialities of his doctrine or whether he continued merely to apply it in defense of free Negroes and mulattoes. Phraseologically the system of constitutional protection he had invoked with reference to the property rights and earning power of Negroes was equally applicable to the protection of the property rights and earning power of corporations. ${ }^{105}$ Did his zeal as an enemy of slavery and as

104. See his speech on President Buchanan's Message, wherein he denied that the Supreme Court was "the final arbiter on all questions of political power." [CoNG. Grone, 36th Cong., 1st Sess. (1860) 1839]. See also 3 Warren, op. cit. supra note 64, at 171, 189.

105. It is of particular interest to note how the chance provisions of the Oregon Constitution barring Negroes from owning property and making contracts led Bing- 
a defender of the Union prevent him from seeing this fact? Did it blind him to the needs and interests of corporations? Or did his neoLockian fervor in behalf of the rights of property - all property, excepting that in slaves - awaken him to the possibility that corporations, since they were "persons" in common legal parlance, might also be "persons" within the meaning of the due process clause? Did Bingham come to extend to corporations - or to shareholders - the same substantive protection he extended to Negroes? In short, did Bingham's views remain static during these years? Or did they prove as flexible and dynamic as during the Fifties? Did the Civil War, which raised a host of problems relating to business and corporations, direct attention to such matters; or did it obscure and crowd out their consideration? The alternative possibilities here balance one another so nicely that even speculation is difficult; yet obviously these are the terms upon which future decision must rest. The charge of "conspiracy" can eventually be maintained only if it is shown that some force or influence caused Bingham to broaden his application of the clause to include corporations - either sometime prior to 1866 , or while the Fourteenth Amendment was before the Joint Committee. Evidence bearing upon these possibilities the writer proposes to review at a later date.

ham into a fundamentally laissez faire usage of due process which anticipated the decisions in Allgeyer v. Louisiano [165 U. S. 578 (1897)] and Smyth v. Ames [169 U. S. $466(1898)]$ by nearly forty years. 